\begin{tabular}{|c|c|}
\hline \multirow{3}{*}{ 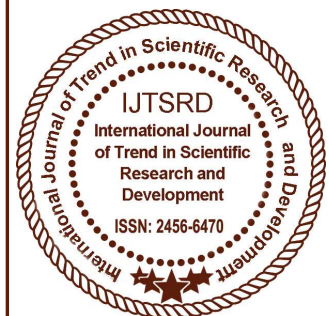 } & $\begin{array}{l}\text { International Journal of Trend in Scientific } \\
\text { Research and Development (IJTSRD) }\end{array}$ \\
\hline & International Open Access Journal \\
\hline & ISSN No: 2456 - 6470 | www.ijtsrd.com | Volume - 1 | Issue - 6 \\
\hline
\end{tabular}

\title{
A Research on Decisive Factors for the Progress of Self Help Groups in Prakasam District, Andhra Pradesh
}

\section{Chidipothu Srinivasa Rao}

M.B.A.,M.COM.,LLM.,(Ph.D), Research Scholar at Acharya Nagarjuna University \& Assistant Professor at PACE Institute of Technology \& Sciences, Department of Management, Vallur, Prakasam

\author{
Dr. N. Venkateswara Rao \\ M.B.A.,M.COM.,M.Phil.,Ph.D, Assistant Professor at \\ Acharya Nagarjuna University P.G Centre, \\ Department of Commerce \& Business \\ Administration, Ongole
}

\section{ABSTRACT}

In Developing countries like India industrialisation is crucial for the faster growth of the nation and standard living of the people also increases. But the basic problem lies with establishment of new business in India, even though people are interested to work but the there's a deficiency in getting the initial investment. So in order cater the financial needs to the entrepreneurs the governments developed and introduced self help groups and also government directed banks and other financial institutions to provide micro finance to that self help groups. By making use of those funds they can fulfil their need of funds. SHGs introduced to empower rural women, who are not in a position to cater financial needs women in Prakasam District.

Keywords: Self help groups, Prakasam District, micro finance, women empowerment

\section{INTRODUCTION}

Self Help Groups (SHGs) Self help groups are a homogenous group of 10-20 individuals who come together for saving and internally helping each other in times of need. Group members are engaged in livelihood activities such as running a retail shop, cattle rearing, zari work, tailoring jobs, making candles, artificial jewelers etc. Each individual saves a fixed amount on a monthly basis. Our Self Help Group-Bank Linkage Programme (SBLP) aims to deliver financial products $\&$ services to the section of Indian population that lacks access to formal banking.

This segment, often from the lower income, meets its financial needs through informal sources such as money lenders, traders, family and friends etc.

Microfinance is a way to promote economic development, employment and growth through the support of micro-entrepreneurs and small businesses for others it is a way for poor to manage their finances more effectively and take advantage of economic opportunities while managing the risks. The terms have evolved-from micro-credit to micro-finance, and now 'financial inclusion'.

Many studies have tried to assess its impacts. Proponents often claim that microfinance lifts people out of poverty, but the evidence is mixed. What it does do, however, is to enhance financial inclusion. Microfinance is a broad category of services, which includes microcredit.

Due to diverse contexts in which microfinance operates, and the broad range of microfinance services, it is neither possible nor wise to have a generalized view of impacts Microfinance may create. Microcredit is only about provision of credit services to poor clients only one of the aspects of micro finance, and the two are often confused. Critics often point to some of the ills of micro-credit that can create indebtedness.

The SHGs are also encouraged to take up livelihood activities, for which skill training is provided by 
certain NGOs. The members of the SHG are encouraged to save and internally lend the savings to members during times of need. SHPIs also provide knowledge on managing books of accounts. However, these sources have their own limitations. Under SBLP, 10-20 individuals are organized in groups known as Self Help Groups (SHGs) by NGOs commonly known as Self Help Promoting Institutions (SHPI).

Banks lend to SHGs after assessing their credit worthiness on parameters such as group discipline, regularity of meetings, savings, rotation of funds, maintenance of books of accounts, group record keeping, repayment of loans etc. SHGs get linked to banks via NGOs, for opening savings account and for their credit requirements.

\section{OBEJECTIVES AND PRINCIPLES OF MICRO FINANCE}

Microfinance means building permanent local institutions. Microfinance also means integrating the financial needs of poor people into a country's mainstream financial system.
Microfinance must be useful to poor households: helping them raise income, build up assets and/or cushion themselves against external shocks.

Poor people need not just loans but also savings, insurance and money transfer services.

$>$ "Microfinance can pay for itself." Subsidies from donors and government are scarce and uncertain and so, to reach large numbers of poor people, microfinance must pay for itself.

"The job of government is to enable financial services, not to provide them.".

$>$ "Donor funds should complement private capital, not compete with it." "The key bottleneck is the shortage of strong institutions and managers.

"Donors should focus on capacity building. Interest rate ceilings hurt poor people by preventing microfinance institutions from covering their costs, which chokes off the supply of credit.

Microfinance institutions should measure and disclose their performance both financially and socially.

\section{CONTRAST BETWEEN PRE-SELF HELP GROUPS VS POST-SELF HELP GROUPS}

\section{PRE-SHG}

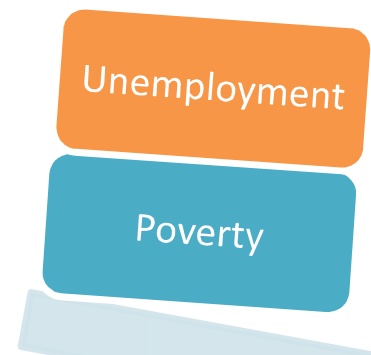

POST-SHG

\section{Entrepreneurs}

Growth of

Nation

Poverty

Eradication

SOURCE: External Data Sources (Open-Access Govt Database) 


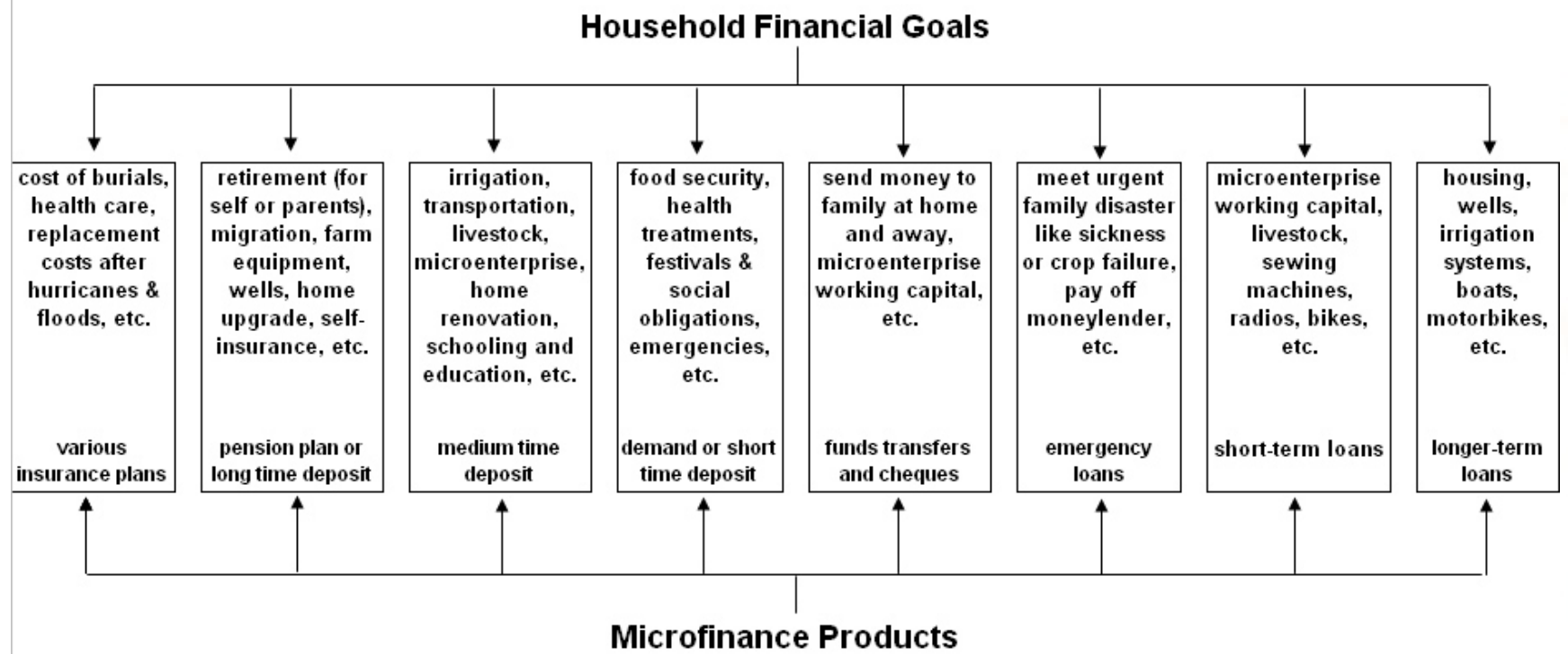

Source: Brett Matthews, Mathwood Consulting Company.

\section{THE WAY OF USAGE OF MICRO FINANCE}

The basic problem that poor people face as money managers is to gather a 'usefully large' amount of money. Building a new home may involve saving and protecting diverse building materials for years until enough are available to proceed with construction. Children's schooling may be funded by buying chickens and raising them for sale as needed for expenses, uniforms, bribes, etc. Because all the value is accumulated before it is needed, this money management strategy is referred to as 'saving up.

Often, people don't have enough money when they face a need, so they borrow. A poor family might borrow from relatives to buy land, from a moneylender to buy rice, or from a microfinance institution to buy a sewing machine. Since these loans must be repaid by saving after the cost is incurred, Rutherford calls this 'saving down'. Rutherford's point is that microcredit is addressing only half the problem, and arguably the less important half: poor people borrow to help them save and accumulate assets. Microcredit institutions should fund their loans through savings accounts that help poor people manage their myriad risks.

\section{NEED FOR THE STUDY}

To find out the a research on decisive factors for the progress of self help groups in Prakasam district ,Andhra Pradesh.

\section{REVIEW OF LITERATURE}

$>$ Sahu Lopamudra, Singh Suresh K, (2012), A qualitative study on role of help group in women empowerment

Manisha Sharma and Vishal Sarin, (2011), exploring the benefits of microfinance organizations for poverty alleviation.

S.Poominathan, Dr.s.amilan (2016) explained about the impact of microfinance on women empowerment through self help groups.

\section{SCOPE OF THE STUDY}

$>$ This research can extend to know the impact of micro finance to entire growth of all over country.

$>$ This research methodology can be used to know the effect of micro finance on all other sectors of business in India.

This research can be extend to know future prospectus of self help groups

\section{HYPOTHESIS}

H0: There is no impact of providing micro finance on the growth of self help groups

H1: There is impact of providing micro finance on the growth of self help groups

\section{POPULATION FOR THE STUDY}

For doing this research the total population is the members of self help groups who received micro finance grants in 56 mandals which consists of 1081 villages entire Prakasam district. 
International Journal of Trend in Scientific Research and Development (IJTSRD) ISSN: 2456-6470

Each mandal have self help groups as well as micro finance facility to them they are considered as population to this research

\section{SAMPLE FOR THE STUDY}

$>$ Because of the money constraint and time constraint from the above total population of 56 mandals separated

$>$ Examiner considered 10 members from each mandal. In prakasam district total 56 mandals, sample size is 560. Here self help group members were taken based on random sampling technique to study the impact of micro finance on self help groups.

\section{RESEARCH METHODOLOGY}

Table 1: Based on Location with banking facilities Parameter of the Respondents

\begin{tabular}{|l|l|l|}
\hline Particulars & $\begin{array}{l}\text { No. } \\
\text { Frequency }\end{array}$ & $\begin{array}{l}\text { Percentage } \\
\text { value }\end{array}$ \\
\hline Only one & $\mathbf{1 6 8}$ & $\mathbf{3 0}$ \\
\hline Two banks & $\mathbf{1 9 6}$ & $\mathbf{3 5}$ \\
\hline Three banks & $\mathbf{1 1 2}$ & $\mathbf{2 0}$ \\
\hline Four and more & $\mathbf{8 4}$ & $\mathbf{1 5}$ \\
\hline TOTAL & $\mathbf{5 6 0}$ & $\mathbf{1 0 0} \%$ \\
\hline
\end{tabular}

Source: Primary Data collected from the respondents

Interpretation: From the above it is clear that majority percentage is from two banks location with banking facilities, they covered $35 \%$ in terms of beneficiaries are concerned.

Table 2: Based on Size of house of the Respondents

\begin{tabular}{|c|c|c|}
\hline Particulars & $\begin{array}{ll}\text { No. } & \text { of. } \\
\text { Frequency }\end{array}$ & $\begin{array}{l}\text { Percentage } \\
\text { value }\end{array}$ \\
\hline Hut & 140 & 25.00 \\
\hline $\begin{array}{ll}\text { Single } & \text { room } \\
\text { house } & \\
\end{array}$ & 252 & 45.00 \\
\hline $\begin{array}{l}\text { Double room } \\
\text { house }\end{array}$ & 120 & 21.42 \\
\hline Building & 48 & 8.57 \\
\hline TOTAL & 560 & $100 \%$ \\
\hline
\end{tabular}

Source: Primary Data collected from the respondents

Interpretation: From the above it is clear that majority percentage of size of the house is single room house, they covered $45 \%$ in terms of beneficiaries are concerned.
Table 3: Based on working people in the family Parameter of the Respondents

\begin{tabular}{|l|l|l|}
\hline Particulars & $\begin{array}{l}\text { No. } \\
\text { Frequency }\end{array}$ & of. \\
\hline Only one & $\begin{array}{l}\text { Percentage } \\
\text { value }\end{array}$ \\
\hline Two persons & $\mathbf{8 0}$ & $\mathbf{7 1 . 4 2}$ \\
\hline Three persons & $\mathbf{6 5}$ & $\mathbf{1 4 . 2 8}$ \\
\hline Four and more & $\mathbf{1 5}$ & $\mathbf{1 1 . 6 0}$ \\
\hline TOTAL & $\mathbf{5 6 0}$ & $\mathbf{2 . 6 8}$ \\
\hline
\end{tabular}

Source: Primary Data collected from the respondents

Interpretation: From the above it is clear that majority percentage of Based on working people in the family Parameter of the Respondents is only one, they covered $71.42 \%$ in terms of beneficiaries are concerned.

Table 4: Based on Educated but Unemployed people in the family of the Respondents

\begin{tabular}{|l|l|l|}
\hline Particulars & $\begin{array}{l}\text { No. } \\
\text { Frequency }\end{array}$ & of. \\
Nil & $\begin{array}{l}\text { Percentage } \\
\text { value }\end{array}$ \\
\hline Single person & $\mathbf{1 2 0}$ & $\mathbf{5 7 . 1 4}$ \\
\hline Two persons & $\mathbf{8 0}$ & $\mathbf{2 1 . 4 2}$ \\
\hline Three persons & $\mathbf{2 5}$ & $\mathbf{1 4 . 2 8}$ \\
\hline Four and more & $\mathbf{1 5}$ & $\mathbf{4 . 4 6}$ \\
\hline TOTAL & $\mathbf{5 6 0}$ & $\mathbf{2 . 6 8}$ \\
\hline
\end{tabular}

Source: Primary Data collected from the respondents

Interpretation: From the above it is clear that majority percentage of Based on Educated but Unemployed people in the family of the Respondents is Nil, they covered $57.14 \%$ in terms of beneficiaries are concerned.

Table 5: Based on Group Cohesiveness Parameter of the Respondents

\begin{tabular}{|l|l|l|}
\hline Particulars & $\begin{array}{l}\text { No. } \\
\text { Frequency }\end{array}$ & $\begin{array}{l}\text { Percentage } \\
\text { value }\end{array}$ \\
\hline $\begin{array}{l}\text { Completely } \\
\text { satisfactory }\end{array}$ & $\mathbf{1 6 0}$ & $\mathbf{2 8 . 5 7}$ \\
\hline Satisfied & $\mathbf{1 4 0}$ & $\mathbf{2 5}$ \\
\hline Can't say & $\mathbf{1 2 5}$ & $\mathbf{2 2 . 3 2}$ \\
\hline Dissatisfied & $\mathbf{8 0}$ & $\mathbf{1 4 . 2 8}$ \\
\hline $\begin{array}{l}\text { Completely } \\
\text { dissatisfied }\end{array}$ & $\mathbf{5 5}$ & $\mathbf{9 . 8 2}$ \\
\hline TOTAL & $\mathbf{5 6 0}$ & $\mathbf{1 0 0 \%}$ \\
\hline
\end{tabular}

Source: Primary Data collected from the respondents

Interpretation: From the above it is clear that majority percentage of Based on Educated but Unemployed people in the family of the Respondents 
is completely satisfied, they covered $28.57 \%$ in terms of beneficiaries are concerned.

Table 6: Proper Government Subsidies Parameter of the Respondents

\begin{tabular}{|c|c|c|}
\hline Particulars & $\begin{array}{ll}\text { No. } & \text { of. } \\
\text { Frequency }\end{array}$ & $\begin{array}{l}\text { Percentage } \\
\text { value }\end{array}$ \\
\hline $100 \%$ received & 80 & 14.29 \\
\hline $\begin{array}{l}\text { More } 70 \% \\
\text { received }\end{array}$ & 102 & 18.21 \\
\hline $50-70 \%$ & 121 & 21.60 \\
\hline $30-50 \%$ & 135 & 24.10 \\
\hline Less than $30 \%$ & 95 & 16.96 \\
\hline Nil & 27 & 4.82 \\
\hline TOTAL & 560 & $100 \%$ \\
\hline
\end{tabular}

Source: Primary Data collected from the respondents

Interpretation: From the above it is clear that majority percentage of Proper Government Subsidies Parameter of the Respondents is $30-50 \%$, they covered $24.10 \%$ in terms of beneficiaries are concerned.

Table 7: Based on size of land holding Parameter of the Respondents

\begin{tabular}{|c|c|c|}
\hline Particulars & $\begin{array}{l}\text { No. } \\
\text { Frequency }\end{array}$ & $\begin{array}{l}\text { Percentage } \\
\text { value }\end{array}$ \\
\hline Nil & 290 & 51.79 \\
\hline Upto one acre & 175 & 31.25 \\
\hline $\begin{array}{l}\text { Two acre - } \\
\text { three acre }\end{array}$ & 61 & 10.89 \\
\hline $\begin{array}{l}\text { Four acre }- \text { six } \\
\text { acre }\end{array}$ & 23 & 4.11 \\
\hline More six acre & 11 & 1.96 \\
\hline TOTAL & 560 & $100 \%$ \\
\hline
\end{tabular}

Source: Primary Data collected from the respondents

Interpretation: From the above it is clear that majority percentage of Based on size of land holding Parameter of the Respondents is Nil, they covered $51.79 \%$ in terms of beneficiaries are concerned.

Table 8: Based on Occupation Parameter of the Respondents

\begin{tabular}{|l|l|l|}
\hline Particulars & $\begin{array}{l}\text { No. } \\
\text { Frequency }\end{array}$ & $\begin{array}{l}\text { Percentage } \\
\text { value }\end{array}$ \\
\hline No Employment & $\mathbf{1 2 5}$ & $\mathbf{2 2 . 3 2}$ \\
\hline Primary sector & $\mathbf{2 7 5}$ & $\mathbf{4 9 . 1 1}$ \\
\hline $\begin{array}{l}\text { Secondary } \\
\text { Sector }\end{array}$ & $\mathbf{1 3 5}$ & $\mathbf{2 4 . 1 1}$ \\
\hline Tertiary Sector & $\mathbf{2 5}$ & $\mathbf{4 . 4 6}$ \\
\hline TOTAL & $\mathbf{5 6 0}$ & $\mathbf{1 0 0 \%}$ \\
\hline
\end{tabular}

Source: Primary Data collected from the respondents

Interpretation: From the above it is clear that majority percentage of Based on Occupation Parameter of the Respondents is primary sector, they covered $49.11 \%$ in terms of beneficiaries are concerned.

Table 9: Based on SHG as a source - Parameter of the Respondents

\begin{tabular}{|c|c|c|}
\hline Particulars & $\begin{array}{l}\text { No. } \\
\text { Frequency }\end{array}$ & $\begin{array}{l}\text { Percentage } \\
\text { value }\end{array}$ \\
\hline Major Source & 249 & 44.46 \\
\hline Minor Source & 116 & 20.71 \\
\hline Doesn't Impact & 195 & 34.82 \\
\hline TOTAL & 560 & $100 \%$ \\
\hline
\end{tabular}

Source: Primary Data collected from the respondents

Interpretation: From the above it is clear that majority percentage of Based on SHG as a source Parameter of the Respondents is major source, they covered $44.46 \%$ in terms of beneficiaries are concerned.

Table 10: Based on Source of funds (Loans) Parameter of the Respondents

\begin{tabular}{|l|l|l|}
\hline Particulars & $\begin{array}{l}\text { No. } \\
\text { Frequency }\end{array}$ & $\begin{array}{l}\text { Percentage } \\
\text { value }\end{array}$ \\
\hline $\begin{array}{l}\text { Regional Rural } \\
\text { Banks }\end{array}$ & 195 & $\mathbf{3 4 . 8 2}$ \\
\hline Money Lenders & $\mathbf{2 8 5}$ & $\mathbf{5 0 . 8 9}$ \\
\hline $\begin{array}{l}\text { Private } \\
\text { Contracts } \\
\text { (Middlemen) }\end{array}$ & $\mathbf{6 8}$ & $\mathbf{1 2 . 1 4}$ \\
\hline $\begin{array}{l}\text { GOVT Funding } \\
\text { (Misc) }\end{array}$ & $\mathbf{1 2}$ & $\mathbf{2 . 1 4}$ \\
\hline TOTAL & $\mathbf{5 6 0}$ & $\mathbf{1 0 0 \%}$ \\
\hline
\end{tabular}

Source: Primary Data collected from the respondents

Interpretation: From the above it is clear that majority percentage of Based on Source of funds (Loans) - Parameter of the Respondents is money lenders, they covered $50.89 \%$ in terms of beneficiaries are concerned. 
Table 11: Based on - Satisfied with SHG Performance Parameter of the Respondents

\begin{tabular}{|l|l|l|}
\hline Particulars & $\begin{array}{l}\text { No. } \\
\text { Frequency }\end{array}$ & $\begin{array}{l}\text { of. } \\
\text { Percentage } \\
\text { value }\end{array}$ \\
\hline Strongly Agree & $\mathbf{1 1 0}$ & $\mathbf{6 . 7 8}$ \\
\hline Agree & $\mathbf{1 4 5}$ & $\mathbf{2 0 . 7 1}$ \\
\hline $\begin{array}{l}\text { Neither Agree } \\
\text { nor Disagree }\end{array}$ & $\mathbf{1 2 0}$ & $\mathbf{5 1 . 7 9}$ \\
\hline Disagree & $\mathbf{1 1 5}$ & $\mathbf{2 0 . 5 4}$ \\
\hline $\begin{array}{l}\text { Strongly } \\
\text { Disagree }\end{array}$ & $\mathbf{7 0}$ & $\mathbf{1 2 . 5 0}$ \\
\hline TOTAL & $\mathbf{5 6 0}$ & $\mathbf{1 0 0 \%}$ \\
\hline
\end{tabular}

Source: Primary Data collected from the respondents

Interpretation: From the above it is clear that majority percentage of Based on - Satisfied with SHG Performance Parameter of the Respondents is Neither agree nor disagree, they covered $51.79 \%$ in terms of beneficiaries are concerned.

\section{LIMITATIONS FOR THE STUDY}

This study taken only one district to do the research

Many respondents are can't be able to understand the questions of research because of illiteracy, so the observer noted the entire primary data.

Parameters are limited for this research

\section{SUGEESTIONS}

Government should help self help groups by providing necessary subsides to the rural poor women by introducing various schemes

\section{CONCLUSION}

After conducting the P-TEST researcher got 0.02 value. Hence if in case the $P$ value greater than 0.05.The null hypothesis is accepted and in that we conclude There is no impact of providing micro finance to the growth of self help groups. On the other side of coin if $p$ value is less than 0.05 then null hypothesis is rejected i.e., There is impact of providing micro finance to the growth of self help groups. In this research evaluator got 0.02 value which means reject the null hypothesis. i.e., there a clear impact of providing micro finance on the growth of self help groups.

\section{REFERENCES}

1) zakir Husain, diganta mukarjee (2012), self help groups and empowerment of women

2) sanjay kanti das, Amalesh bhowal(2013), self help groups as an empowerment model; perceptions of direct stakeholders.

3) Dr. Suprabha (2014) empowerment of self help groups towards micro enterprise development

4) S chakravarty, A N Jha (2012), health care and women's empowerment: the role of self help groups.

5) Mula G.and Sarker S.C, (2013).Impact of Microfinance on women empowerment

6) Sahu Lopamudra, Singh Suresh K, (2012).A qualitative study on role of help group in women empowerment

7) Manisha Sharma and Vishal Sarin, (2011). Exploring the benefits of microfinance organizations for poverty alleviation

8) Lakshimi Ramachandar and Pertti J.Pelto, (2009). Self-help groups growth indicators

9) Thalavai Pillai.N and Nadarajan.s, (2015). Impact of micro credit SHG

10) Ananthi, N. (2010). A study on women empowerment because of micro finance 